\title{
ORGANIZATIONAL SUPPORT OF IMPLEMENTATION OF COMMUNICATIVE PROJECTS IN THE ACTIVITY OF PUBLIC ADMINISTRATION BODIES
}

\begin{abstract}
Nataliia Gavkalova ${ }^{1}$, Viktoriia Hryshyna ${ }^{2}$, Jain Pradeep Kumar ${ }^{3}$
${ }^{I}$ Doctor of Science in Public Administration, Professor of the Department of Public Administration and Regional Economy, Simon Kuznets Kharkiv National University of Economics, Kharkiv, Ukraine, e-mail: ngavl@ukr.net, ORCID: https://orcid.org/0000-0003-1208-9607

${ }^{2}$ Ph.D., lecturer of the Department of Public Administration and Regional Economy, Simon Kuznets Kharkiv National Economic University of Economics, Kharkiv, Ukraine, e-mail: IVictoria77@gmail.com, ORCID: https://orcid.org/0000-0001-8341-1486

${ }^{3}$ Postgraduate student of the Department of Public Administration and Regional Economy, Simon Kuznets Kharkiv National Economic University of Economics, Kharkiv, Ukraine, e-mail:

Dzhain.Pradip.Kumar@hneu.net
\end{abstract}

Abstract. The article analyzes the organizational support for the implementation of communicative projects of public administration bodies. Arguments became the basis for determining the purpose of the study as a justification for the need for organizational support for the implementation of communication projects in order to improve the activities of public administration bodies. When processing the materials, the method of analysis and synthesis was used to determine the essence of the concepts. The generalization method was used in terms of presentation of the conceptual scheme of meaningful characteristics of the communicative project in the activity of public administration bodies. The conceptual scheme of meaningful characteristics of the communicative project is formed, which consists of the purpose, complex of actions, components of development and tasks of realization of communicative projects. This will allow a comprehensive approach to the development and further implementation of communication projects with timely decision-making on targeted changes to certain communication systems or their individual elements in case of negative changes in project activities, or to preserv of the existing state, if will be positive dynamics of communicative activity of public administration bodies.

Keywords: project, communication projects, project approach, public administration.

JEL Classification: H19, H43

Formulas: 0; fig.: 2; tabl.: 0; bibl.: 15

Introduction. Today, in the context of systemic transformations in the activity of public administration bodies, Ukraine has begun to pay considerable attention using of new management methods and of advanced management technologies wich focused on the application of the concept of project management. In order to achieve the effectiveness of public administration, the innovative direction of project management is the implementation of communication projects in the activities of public administration, which will have a positive impact on achieving the planned results and making effective management decisions. Therefore, today the issue of organizational support for the implementation of communication projects in the activity of public administration bodies is largely relevant for to achieve management goals and the formation of a positive image of public administration.

Literature review. Problems of communicative projects in public administration have been studied in the works of such scientists N. Gavkalova, N. Drahomyretska, A. Chemerys, V. Dreshpak, O. Nepomnyashchy and others. Given the important research of the above authors, it should be noted the need to highlight 
key aspects of organizational support for the implementation of communication projects in the activity of public administration bodies.

Aims. Arguments became the basis for determining the purpose of the study as a justification for the need for organizational support for the implementation of communication projects in order to improve the activities of public administration bodies.

To achieve this purpose it is necessary to solve the following tasks:

- to explore the definition of "project", "communicative project";

- to form a conceptual scheme of substantive characteristics of the communicative project in the activities of public administration bodies;

- to characterize the phases of the life cycle of the communicative project in the activities of public administration bodies.

Methods. When processing the materials, the method of analysis and synthesis was used to determine the essence of the concepts. The generalization method was used in terms of presentation of the conceptual scheme of meaningful characteristics of the communicative project in the activity of public administration bodies.

Results. Projects, programs and development strategies are recognized as the most important elements in achieving the strategic goals of the organization both in the business environment and in the public sector. Concepts of development strategy, project management have become key conditions in the current activities of public administration bodies in the implementation of public policy, provision of services, development of national programs or use of material and financial resources [1].

Project management in the field of public administration contains two components. The methodological component includes a set of knowledge, skills, methods, tools and technologies of project management that are necessary for project implementation. The organizational component consists of a project team that manages the project implementation process. Given that project development and implementation takes place in a dynamic environment, this requires constant feedback from project stakeholders [2].

The definition of "project" should be analyzed for a deeper understanding of the essence of the communicative project in the field of public administration.

$\mathrm{Yu}$. Kovbasyuk defines the project as a unique set of coordinated works of a given content with defined start and end dates, limited cost and implementation time, which are aimed at achieving the planned goals in terms of duration, cost and satisfaction of participants [3].

The Law of Ukraine "On Cooperation of Territorial Communities" contains an interpretation of the definition of a joint project, which defines it as a set of measures carried out by local governments at the expense of local budgets and other sources not prohibited by law and aimed at socio-economic and cultural development territories [4].

O. Nepomnyashchy defines the definition of "project" is a process that has limited time, time and may be limited by financial flows, aimed at achieving specific unique goals and objectives in various sectors of the economy and social development " [5]. 
A. Chemeris understands the project in the public sphere as a set of interconnected logically structured tasks and activities that are organized on a timeline. The project aims to solve the most important problems of development of the state, individual sectors of the economy, administrative-territorial units or territorial communities, organizations and institutions, which in turn are carried out in conditions of financial and other resource constraints in a timely manner [6].

Examining the definition of "project" O. Lashchenko and N. Seryogin define its double meaning. On the one hand, the authors emphasize that it is an activity, a set of processes that involves a set of specific actions to achieve certain goals. On the other hand, it is a system of tasks, technical and organizational documents, which describe and justify a set of actions to achieve predetermined specific goals. Researchers summarize that a project should be understood as a document that uses specific methods and tools to describe, justify and detail certain activities (set of processes) to achieve a predetermined and desired result with clearly defined resources in a timely manner [2].

Communicative project means a special form of reflection of needs, interests, moods, aspirations, which are expressed in a certain symbolic form. This is a special technology for building government-public relations. It involves investing a certain amount of resources (financial, material and human) in order to achieve goals and planned results in a timely manner with public involvement in management processes [7].

In the context of forming a corporate culture, E. Kaverin argues that communication projects should be considered as a strategic system of action. They should be aimed at achieving a cascade of corporate goals, namely strategic goals (broadcasting corporate myths and traditions, promoting corporate values, initiating interaction with partners, etc. Communicative projects aimed at achieving motivational goals, namely building a positive creative atmosphere and teamwork goals (team building, detection of hidden professional and personal reserves of staff) [8].

It should be noted that in the field of activity of some scientists, communication projects are considered in the context of social, taking into account that project activities involve, above all, the relationship between stakeholders. But most scholars are still inclined to the organizational and communication aspect, explaining that communication and management are aimed at regulating the joint activities of individuals, groups, society, which aims to achieve economic effect, and therefore do not exclude the economic component contained in projects.

Describing the implementation of communication projects in local governments, N. Drahomyretska notes that project activities belong to the category of innovative creative activities, as it involves the transformation of reality, based on appropriate technology that can be unified to master and improve. The author argues that the implementation of communication projects is unique in that it provides an opportunity to involve the public in management processes. N. Drahomyretska characterizes the project of communicative activity of public administration as an intellectual model, the implementation of which contributes to the intellectual, 
emotional and behavioral construction of the recipient of the message, and therefore, the project is to some extent communicative [7].

In the context of the study, it is advisable to present a conceptual scheme of the substantive characteristics of the communicative project in the activities of public administration bodies (Fig. 1).

\begin{tabular}{|c|c|}
\hline \multicolumn{2}{|c|}{$\begin{array}{l}\text { The purpose of the communication project }(\mathrm{CP}) \text { is to influence the communication } \\
\text { system or its individual elements, to create unique products, services or results }\end{array}$} \\
\hline Signs of the CP & Substantive components of the CP \\
\hline $\begin{array}{ll}\checkmark & \text { target orientation } \\
\checkmark & \text { time constraint } \\
\checkmark & \text { system operation } \\
\checkmark & \text { limited resources } \\
\checkmark & \text { the presence of a life cycle } \\
\checkmark & \text { quantity of measurement }\end{array}$ & $\begin{array}{l}\checkmark \text { goal (idea) } \\
\checkmark \text { resources (social, financial, material and } \\
\text { technical, informational) } \\
\checkmark \text { management tools (methods, technologies) } \\
\checkmark \text { results (products) }\end{array}$ \\
\hline A set of measures of the $\mathrm{CP}$ & Components of the $\mathrm{CP}$ development \\
\hline $\begin{array}{l}\checkmark \text { innovative } \\
\checkmark \text { research } \\
\checkmark \checkmark \text { design and engineering } \\
\checkmark \checkmark \text { socio-economic } \\
\checkmark \checkmark \text { organizational }\end{array}$ & $\begin{array}{l}\checkmark \text { definition of project requirements } \\
\checkmark \text { development of information materials packages } \\
\checkmark \text { definition of requirements for texts } \\
\checkmark \text { determining the requirements for the initiators } \\
\checkmark \text { of communicative activities } \\
\checkmark \text { team organization } \\
\checkmark \text { organization of joint activities }\end{array}$ \\
\hline \multicolumn{2}{|c|}{ Tasks of the $\mathrm{CP}$ implementation } \\
\hline \multicolumn{2}{|c|}{$\begin{array}{l}\checkmark \text { ensuring dialogue between government, business and civil society } \\
\checkmark \text { implementation of joint projects of informational, analytical-research, charitable } \\
\text { and social orientation } \\
\checkmark \text { formation of a unified system of assessment and vision of strategic directions of } \\
\checkmark \text { the region's development } \\
\checkmark \text { strengthening the role of local self-government } \\
\checkmark \text { formation of a positive image }\end{array}$} \\
\hline
\end{tabular}

Figure 1. Conceptual scheme of meaningful characteristics of the communicative Source: developed by the author project in the activity of public administration bodies

Communication project ideas are developed depending on the target audiences of projects, which can be aimed at both external audiences (stakeholders, the public, public authorities, etc.) and internal audiences of public administration. As part of the communication project, depending on the goals and objectives, special events can be organized to convey corporate views, ideas and to engage target audiences with corporate values.

The content components of the project highlighted in Figure 1. have a certain set of characteristics, are a confirmation that the project should be classified as communicative. Important features of a communicative project in terms of forming the corporate culture of united territorial communities is that even if projects are 
similar, they are never implemented in the same environment and context, so communicative projects are unique. They are temporary, so they are determined by the specific beginning and end of each project.

Therefore, the start time can be set, as the project starts with the term for which the temporary project team is organized and the key team is appointed. Because projects are not repetitive, are performed for a product with unique content and provide certain conditions, fulfilling their missions is not always an easy task and is accompanied by some uncertainty. This uncertainty leads to risks due to uncertain information, immature or untested technology and unpredictable factors. In projects, these risks are overcome with the help of the project manager and the combined knowledge and creativity of team members. The project team is created and operates during the period of implementation of the communicative project. Its composition and functions depend on the scale, complexity and other characteristics of the communicative project that determine its uniqueness.

The main limitations in the implementation of projects are must be taken into account in planning is the so-called project triad, which includes time, budget and quality of work. Like any project, a communication project has a life cycle. It is the period from the appearance of the concept of the future product of the project or the requirements for it (information) to the moment of putting this product into operation (closing). The life cycle of a communicative project consists of several phases, each of which involves the implementation of certain actions that lead to an intermediate result. There is no generally accepted division into phases, but all phases are performed in chronological order. It is important that at the end of each phase it is necessary to evaluate, provide justification for further implementation of the communicative project [3] (Fig. 2)

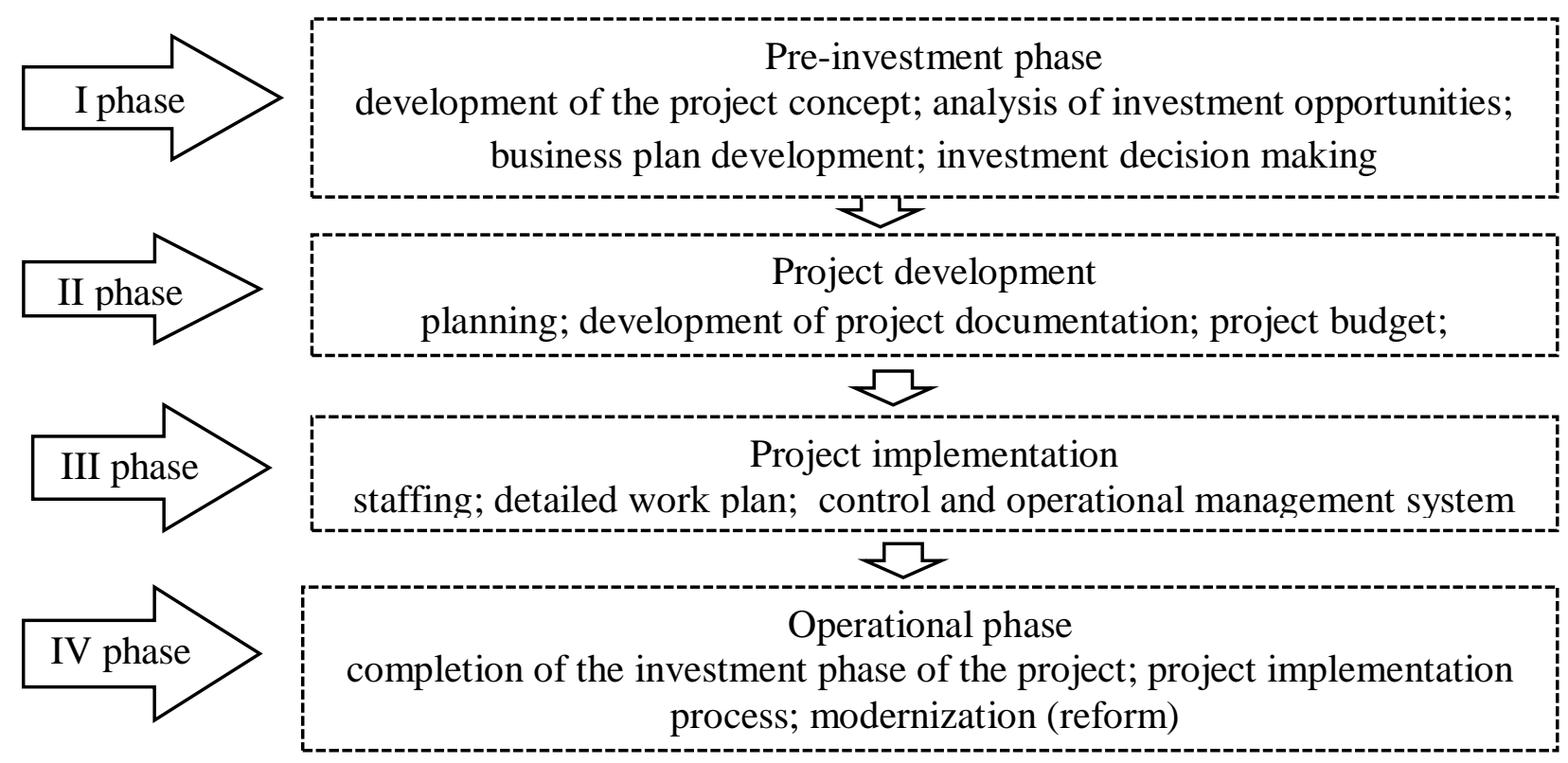

Figure 2. Characteristics of the phases of the life cycle of a communicative

Source: generalized on the basis of [3;7;9]

project 
The expediency of implementation and realization of communicative projects in the activity of public administration bodies first of all is explained in the direction of realization of the strategy of development of the territory $[9$,$] . In order to meet the$ needs of the target audience, it is important for communication projects to establish feedback with the public, stakeholders.

Communication projects are implemented in various forms. As an example of communication projects in the field of public administration V. Dreshpak notes communication strategies of public authorities at various levels, media campaigns using media systems, etc.[11].

The activities of public relations and mass media (media) services of public administration bodies can also be considered in the aspect of organization and implementation of media campaigns (media projects) of different scales and duration. Thus, it is possible to clearly define the goal to be achieved, rational use of resources, accurately outline the result, which in a given time can be assessed by certain criteria. In this context, we consider the media campaign as a communicative project that has to go through stages: assessing the situation and identifying the problem; goal and audience definition; selection of mass communication channels and techniques of influence; resource planning; actual project implementation through communication; evaluation of the result [12, pp. 95-100].

Therefore, in order to implement and evaluate communication projects, financial and logistical support of projects in the activities of public administration, first of all requires a fundamental solution to the organizational structure of communication project management.

In general, according to $M$. Drahomyretska, in the organization and implementation of communicative activities the project is such a tool that allows to organize the communicative activities of public administration at a new level. The development and implementation of these projects in communicative activities, as noted by the scientist, has the following components: determining the requirements for the project; preparation of the verbal component of the project implementation on the development of packages of information materials to explain the actions of the initiators of communicative activities; definition of requirements to texts; requirements for the initiators of communicative activities; selection of a team for project implementation; organization of joint activities with repeaters. The project type of communicative activity is one of the most difficult both in terms of management and in terms of practical implementation of tasks. It requires creativity, diligence, flexibility, ability to interact with different organizations, the ability to make non-standard decisions, the ability to find the least expensive ways to solve problems, etc. [13, pp. 24-26].

In order to effectively communicate N. Drahomyretska [7] proposes to implement a project approach to management, which should be accompanied by structural changes, namely to move to a two-tier structural organization, which provides a level of formal administration, including all types of management and project level. From a team organization perspective, the project level may include temporary and permanent project teams. From the standpoint of the direction of 
work, the project level is related to the communicative activities of public administration bodies.

For the development and implementation of programs and projects in the field of public administration I. Chikarenko [14] provides a number of arguments about the feasibility of applying the project approach:

- project management is a universal concept that can be applied to any project in all fields and areas, from education, science and medicine to heavy industry, the armed forces and the defense industry;

- on the basis of project management it is possible to effectively solve the problem of control of deadlines and especially costs (both by government agencies and the public); project management methods are flexible, they can be used in any organization and at the same time harmoniously adjusted with strategic management and organizational strategy;

- on the basis of project management it is possible to clearly control and manage the effectiveness of activities, which in other conditions is often difficult to do;

- project approach allows to form a more flexible organizational structure of management, able to respond in a timely manner to changes in internal and external environment;

- the project approach provides a clear division of management goals, objectives, functions and responsibilities for project implementation, which facilitates the evaluation and increases control over the implementation of tasks by subordinates;

- on the basis of the project approach determine the composition of the project tasks, hierarchical structuring on the principle of "tree of works", which allows to include in the project structure the necessary and sufficient tasks;

- the project approach provides an opportunity to conduct an integrated assessment of the socio-economic usefulness of the project on the only main criterion for obtaining a generalized assessment of the effectiveness of public authorities in a particular problem area;

- project management aims to obtain a finished product - the end result, which determines the degree of satisfaction of the needs of citizens;

- project management uses the strategy of targeted rational allocation and use of project resources on the criterion of maximization in order to effectively manage them;

- with the help of the project approach the feedback with the population of the country is carried out that gives the chance to estimate activity of public administration body directly by citizens of the state.

Conclusions. In conclusion, a communicative project is a complex of interrelated activities that are aimed at creating a unique product or service in conditions of time and resource constraints. In the context of the systemic transformation of public administration, the reform of local self-government and the formation of new territorial communities [15], communication projects are of particular importance in addressing a number of organizational, communications, socio-economic issues, namely, improving human resource management, resource provision, and improving public image management. 


\section{Author contributions. The authors contributed equally. Disclosure statement. The authors do not have any conflict of interest. References:}

1. Oliynyk, R. (2019) Project Management: Features of Key Concepts and Applications in the Public Sector. Law and public administration. 2019. № 2 (35), vol. 2. pp. 147 - 151.

2. Laschenko O, Seregina N. (2021) Introduction proyektnoho approach in the activities of the Public Administration Public Administration and Local Government, Issue 1 (48), pp. 113-121 URL: http: //www.dbuapa. dp.ua/zbirnik_dums/2021/2021_01(48)/16.pdf

3. Kovbasyuk, Yu. (2012) Public administration: textbook: in 2 volumes / National Academy of Public Administration under the President of Ukraine: Yu. Kovbasyuk (chairman), K. Vashchenko (deputy chairman), Yu. Surmin (deputy chairman) [etc.], Dnipropetrovsk: NAPA, Vol. 1, 564 p.

4. Law of Ukraine «On cooperation of territorial communities» 17.06. 2014 № 1508-VII. URL: http://zakon4.rada.gov.ua/laws/show/1508-18

5. Nepomnyashchy, O. (2018) Project management as a mechanism to increase efficiency public administration. Public administration and national security. № 1 .

URL: https://www.inter-nauka.com/uploads/public/15391671993694.pdf

6. Chemerys, A. (2012) Development and management of projects in the public sphere: the European dimension for Ukraine: practice. way. Kyiv: Sofia-A, 80 p. URL:https://despro.org.ua/media/articles/10_book_chemeric_17_12_do_druku.pdf 7. Dragomiretska N. (2008) Communicative projects at the regional level and the practice of their implementation in the process of democratic governance / NM Dragomiretska // Theory and practice of public administration, Issue 4, pp. 104-110. - URL: http://nbuv.gov.ua/UJRN/Tpdu_2008_4_17

8. Kaverina, E. (2009) Communication projects and special events as a technology for the development of corporate culture of the university / E. Kaverina // Innovations in education: news. Nizhny Novgorod University. N.I. Lobachevsky, №5, pp. 31-37. URL: https://cyberleninka.ru/article/n/kommunikatsionnye-proekty-ispetsialnye-sobytiya-kak-tehnologii-razvitiya-korporativnoy-kultury-vuza-na-primere-organizatsii

9. Gavkalova, N.; Lola, Yu.; Malyi, I.; Poliakova, H. (2021) The institutional transformation of the digital values of Ukrainian society / N. Gavkalova // Intellectual economics. 15(1). - URL: https://journals.mruni.eu/index.php/ie/article/view/18

10. Sudnickas, T.; Smalskys, V.; Gavkalova, N.; Dzenis, V.; Dzenis, O. (2021) Mechanisms of Information and Analytical Support of Local State Administrations / T. Sudnickas // Journal of Information Technology Management. Volume \& Issue: Volume 13, Special Issue: Advanced Innovation Topics in Business and Management, P. 188 - 203. URL: https://jitm.ut.ac.ir/issue_10477_10801.html

11. Dreshpak, V. (2013) Communicative projects in the field of public administration: meaningful characteristics and organizational support of implementation / V. Dreshpak // Theory and history of public administration. - Public Administration and Local Self-Government, vol. 3 (18), pp. 3 - 12. URL: http://www.irbis-nbuv.gov.ua >irbis nbuv> cgiirbis_64

12. Dreshpak, V. (2006) Press Service of the institution, organization, enterprise: textbook. way. / V. Dreshpak. Dnipro.: Zhurfond. - $124 \mathrm{p}$.

13. Dragomiretska, N. (2007) Communicative activities in public administration: theoretical and methodological aspect: author. dis. Dr. of Science from the state. упр. : 25.00.017 Drahomyretska Natalia Mykhailivna; Nat. acad. state упр. for the President of Ukraine.-K.,-36 p.

14. Chikarenko, I (2004) Project approach as one of the means to increase the efficiency of activity // Theory and practice of public administration. Issue 9. Public administration and local self-government: theses IV International. Science. Congress, Feb. 26. 2004. Kharkiv: Master,. pp. 24 - 26.

15. Gavkalova, N.; Zilinska, A.; Polatay, V.; Liashevska, V. (2020) Organizational support for the development of territorial communities / N. Gavkalova // Public Policy and Administration. Research Journal. - №19 (4), pp. $155-168$. DOI:10.13165/VPA-20-19-4-11 